\title{
Analisis peringkat lokasi potensial taman Kota Depok di tingkat kecamatan menggunakan sistem informasi geografis dan TOPSIS
}

\author{
Revi Hernina*, Yusuf Abdurrohim*, Arif Wicaksono** \\ * Departemen Geografi, Fakultas Matematika dan IPA, Universitas Indonesia, Indonesia \\ ** Bidang Penelitian dan Pengembangan Bappeda Kota Bogor, Indonesia
}

\begin{tabular}{l}
\hline ARTICLES INFO \\
\hline Profil Articles: \\
Sent: 17-10-2019 \\
Approved: 30-5-2020 \\
Published: $30-6-2020$
\end{tabular}

Key words:

taman kota, kecamatan, Sistem Informasi Geografis, TOPSIS

\begin{abstract}
This article provides rank alternatives of 113 potential urban park locations at sub-district level in Depok Municipality. These potential locations were selected because they have areas between $\geqslant 24.000 \mathrm{~m}^{2}$ and $<144.000 \mathrm{~m}^{2}$ based on urban park classification in sub-district level. Three spatial criteria in form of vector datasets, namely road length, potential green open space (GOS) and park area were processed using Geographic Information System (GIS) and then weighted using ranking method. In every column of each location within spatial attribute table, those 3 criteria were processed to provide positive ideal $\left(r^{+}\right)$and negative ideal $\left(r^{-}\right)$solutions using Technique for Order Preference by Similarity to an Ideal Solution (TOPSIS) method. These solutions were computed to generate the relative closeness $\left(c_{i}^{+}\right)$of each location. When input into TOPSIS, road length and GOS status were classified as benefit indices while park area as cost indices. Results show the first rank has $c_{i}^{+} 0.83$, while lowest rank has $c_{i}^{+}$ 0.039. For assessment of TOPSIS results' performance, the demand for park total unit and area for every sub-district were computed from predicted population of 2030 and 2040. Simulated urban park development percentage from TOPSIS results were classified into 3 scenarios, namely scenario I (100\% development), scenario II (50\%) and scenario III $(10 \%)$. It can be concluded that scenario I successfully meet the urban park area demand in 2040 for every sub-district. Moreover, scenario I sufficiently serve park unit demand in 8 sub-districts equal to $72.72 \%$ of the whole sub -districts in Depok Municipality.
\end{abstract}

Artikel ini menyajikan alternatif peringkat dari 113 lokasi potensial taman Kota Depok di tingkat kecamatan. Lokasi potensial ini dipilih karena memiliki luas $\geqslant 24.000 \mathrm{~m}^{2}$ dan $<144.000 \mathrm{~m}^{2}$ berdasarkan klasifikasi taman kecamatan. Tiga kriteria spasial berbentuk data vektor, yaitu panjang jalan, wilayah potensial ruang terbuka hijau (RTH), dan luas lokasi diproses dengan Sistem Informasi Geografis (SIG) kemudian diberi bobot menggunakan metode peringkat. Dalam setiap kolom atribut spasial, 3 kriteria tersebut diproses dengan metode Technique for Order Preference by Similarity to an Ideal Solution (TOPSIS) untuk menghasilkan solusi ideal positif $\left(r^{+}\right)$and ideal negatif $\left(r^{-}\right)$. Nilai solusi ini dikomputasi menjadi nilai relative closeness $\left(c_{i}^{+}\right)$untuk setiap lokasi taman. Kriteria panjang jalan dan wilayah RTH potensial diklasifikasikan sebagai benefit indices sedangkan luas lokasi taman sebagai cost indices. Hasil studi ini menunjukkan bahwa lokasi taman kecamatan potensial dengan peringkat pertama memiliki nilai $c_{i}^{+} 0,83$, sementara peringkat terakhir memiliki nilai $c_{i}^{+}$0,039. Untuk menganalisis kinerja lokasi taman potensial yang dihasilkan TOPSIS terhadap target kebutuhan taman, maka dilakukan prediksi kebutuhan jumlah unit dan luas taman kecamatan berdasarkan proyeksi penduduk tahun 2030 dan 2040. Selanjutnya simulasi prosentase pembangunan taman kecamatan hasil metode TOPSIS diklasifikasi menjadi 3 skenario yaitu skenario I (100\%), skenario II $(50 \%)$, dan skenario III $(10 \%)$. Dapat disimpulkan untuk penerapan skenario I, hasil studi ini 
diprediksikan mampu melayani kebutuhan luas taman kecamatan di Kota Depok sampai tahun 2040. Sedangkan untuk memenuhi kebutuhan unit taman kecamatan sampai tahun 2040, skenario I masih bisa diaplikasikan pada 8 kecamatan atau 72,72\% dari seluruh kecamatan di Kota Depok.

This is an open access article under the CC-BY-SA license

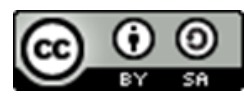

\section{Correspondent Author:}

Revi Hernina

Departemen Geografi

Universitas Indonesia

Gedung H, Kampus UI Depok 16424

Email: revie12@yahoo.com

\section{PENDAHULUAN}

Dalam Rencana Tata Ruang Wilayah Nasional (RTRWN), Kota Depok di Provinsi Jawa Barat termasuk dalam Kawasan Perkotaan Pusat Kegiatan Nasional (PKN). Kota Depok memiliki target Ruang Terbuka Hijau (RTH) ideal 30\% dari luas Kota Depok atau sekitar 6.009 ha. Namun, berdasarkan Perda No.1 Tahun 2015 tentang Rencana Tata Ruang Wilayah (RTRW) Kota Depok 2012-2032, target 30\% luas RTH belum terpenuhi. RTH eksisting tahun 2015 tercatat 3.271,26 ha (16,33\%). RTH tersebut tercatat sekitar 2.016 ha $(10,06 \%)$ merupakan RTH publik dan sekitar 1.256 ha $(6,27 \%)$ merupakan RTH Privat (Pemerintah Kota Depok, 2015). Untuk memenuhi target tersebut, maka perlu dilakukan kajian lokasi potensial RTH di Kota Depok dengan mempertimbangkan kondisi RTH eksisting.

Sebagai salah satu komponen dalam RTH perkotaan, lokasi taman kota di tingkat kecamatan layak untuk dianalisis potensinya sebagai alternatif dalam memenuhi target RTH Kota Depok. Mengacu pada penelitian sebelumnya, taman kota skala kecamatan memiliki radius jangkauan pelayanan yang tinggi seperti taman Kambang Iwak Besak (KIB) di Kota Palembang yang mencapai $\pm 4,14 \mathrm{~km}$ (Mafra, Siswanto, Iqbal, \& Juliantina, 2018). Selain itu, taman skala kecamatan menawarkan fasilitas yang lebih beragam daripada taman kota pada hirarki di bawahnya seperti taman skala kelurahan. Berdasarkan Peraturan Menteri Pekerjaan Umum No. 5/PRT/M/2008, kriteria luas taman kota di tingkat kecamatan adalah $\geqslant 24.000 \mathrm{~m}^{2}$ dan $<144.000 \mathrm{~m}^{2}$. Fungsi taman kota di tingkat kecamatan ini adalah melayani jumlah penduduk \pm 120.000 jiwa yang berada di wilayah administratif kecamatan (Direktorat Jenderal Penataan Ruang, 2008).

Sebelumnya, kriteria yang telah digunakan dalam penentuan lokasi potensial RTH di Kota Depok adalah penggunaan tanah, ketersediaan RTH, dan nilai tanah (Abdurrohim, 2017). Namun hasil penelitian tersebut belum dapat ditentukan peringkat prioritas lokasi taman kota terutama untuk tingkat kecamatan. Padahal, adanya peringkat prioritas lokasi taman kota dapat memudahkan pengambil kebijakan dalam memilih alternatif lokasi pembangunan. Salah satu model dalam penentuan peringkat alternatif lokasi potensial taman kota yang pernah dilakukan adalah kombinasi TOPSIS (Technique for Order Preference by Similarity to an Ideal Solution) dan Sistem Informasi Geografis (SIG) dengan 5 kriteria, yaitu akses ke jalan utama, akses ke permukiman, jarak ke taman dan RTH, jarak ke patahan gempa, jarak ke pusat pendidikan (Qelichi, Oroji, \& Asadi, 2012). Menimbang kesesuaian antara model dan kriteria yang pernah digunakan 
Jurnal Pendidikan Geografi:

Kajian, Teori, dan Praktik dalam Bidang Pendidikan dan Ilmu Geografi

Volume 25, Nomor 2, Jun 2020, Hal 145-160

sebelumnya, maka pada studi ini kriteria yang digunakan adalah panjang jalan, wilayah potensial, dan luas lokasi. Penelitian ini bertujuan untuk menganalisis alternatif peringkat lokasi potensial taman Kota Depok di tingkat kecamatan dengan menggunakan SIG dan TOPSIS.

\section{METODE}

\section{Lokasi Penelitian}

Kota Depok dengan luas 20.029 ha memiliki jumlah penduduk yang cenderung meningkat, dari 240.000 jiwa pada tahun 1982 menjadi 1,2 juta jiwa pada tahun 1999 dan sampai pada tahun 2019 berjumlah sekitar 2,5 juta jiwa (BPS, 2020). Secara administratif, Kota Depok berada di Provinsi Jawa Barat dan berbatasan dengan Kota Tangerang Selatan di barat, Kota Bekasi di timur, Provinsi DKI Jakarta di utara, dan Kabupaten Bogor di selatan. Kota Depok terdiri dari 11 Kecamatan yaitu; Pancoran Mas, Beji, Cipayung, Sukmajaya, Cilodong, Limo, Cinere, Cimanggis, Tapos, Sawangan, dan Bojongsari. Secara geografis, Kota Depok terletak pada koordinat 6 $6^{\circ} 19^{\prime} 00$ " -628 ' $00^{\prime}$ Lintang Selatan dan $106^{\circ} 43^{\prime} 00^{\prime}$ - $106^{\circ} 55^{\prime} 30^{\prime}$ Bujur Timur (Gambar 1).

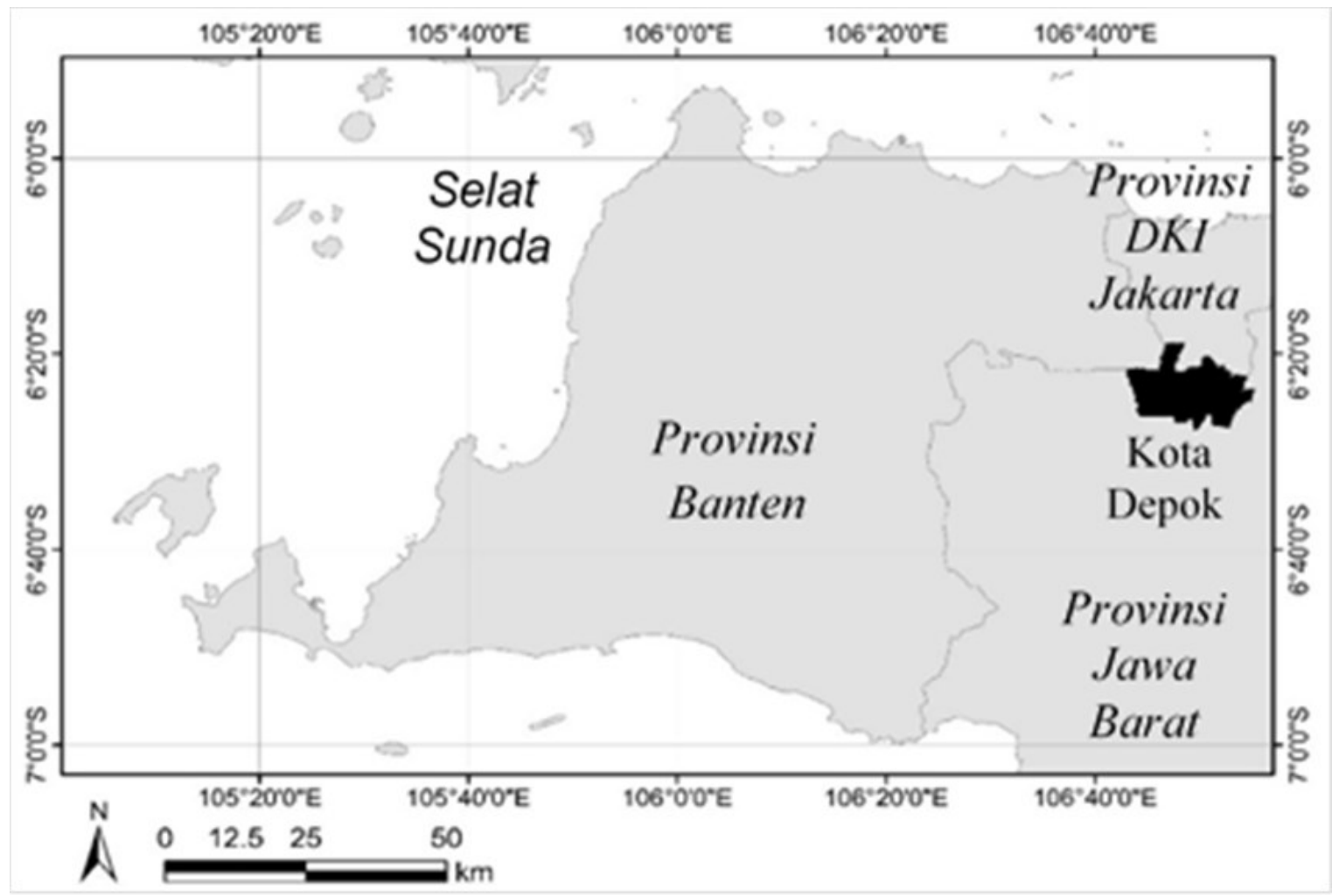

Gambar 1. Lokasi penelitian

(Sumber: Pengolahan data menggunakan ArcGIS) 


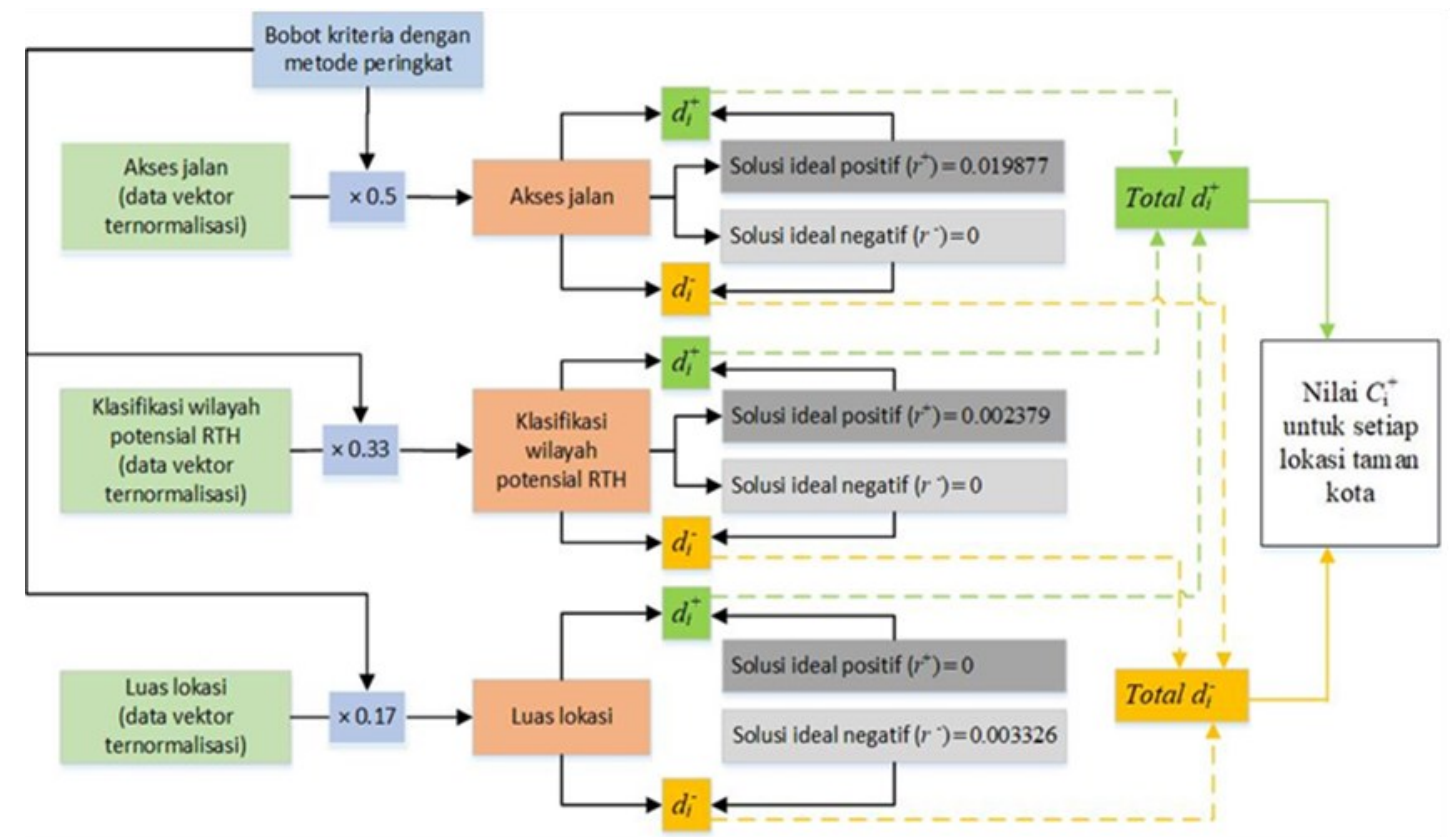

Gambar 2. Alur pikir penelitian

\section{Alur pikir Penelitian}

Data panjang jalan dalam bentuk data vektor diiris dengan poligon lokasi wilayah potensial RTH sehingga masing-masing poligon lokasi potensial memiliki data panjang jalan. Sedangkan luas masing-masing lokasi potensial RTH diperoleh dari menu calculate geometry dalam format attribute table dengan software ArcGIS. Tiga kriteria spasial yaitu panjang jalan, wilayah potensial RTH, dan luas lokasi diberi bobot yang berasal dari metode peringkat. Kemudian data tiap lokasi dinormalisasi untuk masingmasing kriteria. Untuk memperoleh solusi ideal positif setiap kriteria dengan mengidentifikasi nilai maksimum akses jalan, wilayah potensial dan nilai minimum luas lokasi dan sebaliknya untuk solusi ideal negatif. Solusi ideal positif dan negatif berguna untuk menghitung jarak dengan masing-masing data tiap kriteria, dan akhirnya bisa memperoleh nilai $c_{i}^{+}$tiap lokasi. Secara umum alur pikir penelitian dapat dilihat pada Gambar 2.

\section{Kriteria yang digunakan}

\section{Akses jalan}

Kriteria akses jalan digunakan sebagai faktor penentu peringkat lokasi taman kota dalam studi ini dikarenakan menurut Gupta, Roy, Luthra, Maithani, \& Mahavir (2016) jalan utama maupun jalan lokal merupakan akses menuju taman kota. Selain itu, pembangunan sebuah taman kota memerlukan akses jalan baik untuk mengangkut material pembangunan ke lokasi maupun untuk pemeliharaan taman.

\section{Wilayah potensial RTH}

Wilayah potensial RTH di Kota Depok (Abdurrohim, 2017) dianalisis dari kesesuaian lahan RTH menggunakan kriteria Penggunaan Tanah, Nilai Tanah, dan Ketersediaan RTH Menurut Jumlah Penduduk per Kelurahan (Sitorus, Ashri, \& Panuju, 2013; Tontou, Moniaga, \& Rengkung, 2013). Pada artikel ini, klasifikasi penggunaan 
Jurnal Pendidikan Geografi:

Kajian, Teori, dan Praktik dalam Bidang Pendidikan dan Ilmu Geografi

Volume 25, Nomor 2, Jun 2020, Hal 145-160

tanah yang tidak sesuai untuk lokasi potensial RTH adalah : (a) lahan terbangun, (b) badan air, (c) lokasi RTH eksisting.

\section{Luas lokasi taman kota}

Dalam artikel ini, kriteria lokasi taman kota diasumsikan sebagai faktor yang memerlukan biaya dikarenakan semakin luas lokasi taman maka semakin besar biaya yang harus dikeluarkan untuk pembelian lahan maupun pembangunannya. Dengan menggunakan menu attribute query pada $\operatorname{ArcGIS}$, maka setiap lokasi yang memiliki lokasi antara $\geq 24.000 \mathrm{~m}^{2}$ dan $<144.000 \mathrm{~m}^{2}$ dapat dipilih sedangkan yang tidak memenuhi kriteria dihapus dari database spasial.

\section{TOPSIS}

Metode TOPSIS (Technique for Order Preference by Similarity to an Ideal Solution) merupakan metode untuk memeringkat alternatif solusi dengan memilih jarak yang paling pendek dari solusi positif ideal dan jarak yang paling jauh dari solusi negatif ideal (Wei, 2010). Pada penelitian ini, 3 kriteria yaitu; panjang jalan, tingkat potensial RTH, dan luas taman kota dari 113 lokasi diolah dalam TOPSIS. Bobot dari kriteria tersebut dihitung menggunakan metode peringkat (Malczewski \& Rinner, 2015) yaitu dengan rumus:

$$
w_{j}=\frac{n-r_{j}+1}{\sum_{j=1}^{n} n+r_{j}+1}
$$

dimana $w_{j}=$ bobot atribut ke- $j, r_{j}=$ peringkat kriteria ke- $j$, dan $n=$ jumlah kriteria dengan ketentuan bahwa peringkat 1 diberikan kepada kriteria yang paling penting (Tabel 1).

Selanjutnya data ke-3 kriteria tersebut dinormalisasi dengan membagi setiap data dengan jumlah total data per kriteria yang dilakukan melalui rumus:

$$
X_{i}=\frac{x_{i}}{\sum_{i=1}^{n} x_{i}}
$$

dimana $X_{i}=$ data ke- $i$ ternormalisasi, $x_{i}=$ data ke- $i$.

\begin{tabular}{|c|c|c|c|}
\hline Kriteria & $r_{j}$ & $w_{j}$ & Pertimbangan peringkat kriteria \\
\hline Panjang jalan $(k 1)$ & 1 & 0.5 & $\begin{array}{l}\text { Akses jalan sangat dibutuhkan untuk menuju lokasi taman kota } \\
\text { (Gupta et al., 2016). Panjang jalan merupakan salah satu indikator } \\
\text { aksesibilitas taman kota, yang telah digunakan sebelumnya oleh } \\
\text { Meng \& Malczewski (2015) dengan menggunakan jarak terdekat dari } \\
\text { pusat wilayah ke lokasi taman kota. }\end{array}$ \\
\hline $\begin{array}{l}\text { Klasifikasi wilayah } \\
\text { potensial }(k 2)\end{array}$ & 2 & 0.33 & $\begin{array}{l}\text { Pembangunan taman kota bertujuan untuk memenuhi kecamatan } \\
\text { yang masih kurang persentase RTH }\end{array}$ \\
\hline Luas $(k 3)$ & 3 & 0.17 & $\begin{array}{l}\text { Luas taman kota tidak diprioritaskan, disebabkan sudah dilakukan } \\
\text { query luas } \geq 24.000 \mathrm{~m}^{2} \text { dan }<144.000 \mathrm{~m}^{2} \text { sehingga berapapun luas }\end{array}$ \\
\hline
\end{tabular}

Tabel 1. Bobot kriteria untuk penentuan peringkat taman kota di tingkat kecamatan

(Sumber : Pengolahan data) 
Setelah dinormalisasi, setiap data per kriteria diolah menjadi solusi ideal positif $\left(r^{+}\right)$dan solusi ideal negatif $\left(r^{-}\right)$(Tang, Zhu, Liu, Jia, \& Zheng, 2019) dengan rumus sebagai berikut:

$$
\begin{aligned}
& r^{+}=\left\{\left(\max _{1 \leq i \leq m} r_{i j} \mid j \in J^{+}\right),\left(\min _{1 \leq i \leq m} r_{i j} \mid j \in J^{-}\right)\right\} \\
& r^{-}=\left\{\left(\min _{1 \leq i \leq m} r_{i j} \mid j \in J^{+}\right),\left(\max _{1 \leq i \leq m} r_{i j} \mid j \in J^{-}\right)\right\}
\end{aligned}
$$

Dalam hal ini, $k 3$ dikategorikan sebagai cost indices $\left(J^{-}\right)$dikarenakan semakin luas taman maka untuk pembangunannya memerlukan biaya yang besar sedangkan $k 1$ dan $k 2$ merupakan benefit indices $\left(J^{+}\right)$yang menambah keuntungan apabila memilih taman di lokasi tersebut.

Langkah selanjutnya adalah dengan menghitung jarak antara nilai masing-masing lokasi dengan nilai $r^{+}$dengan rumus:

$$
d_{i}^{+}=\sqrt{\sum_{j=1}^{n}\left(r_{i j}-r_{j}^{+}\right)^{2}} \quad, \mathrm{i}=1, \ldots, \mathrm{m}
$$

Dilanjutkan dengan menghitung jarak antara nilai masing-masing lokasi dengan nilai $r^{-}$dengan rumus:

$$
d_{i}^{-}=\sqrt{\sum_{j=1}^{n}\left(r_{i j}-r_{j}^{-}\right)^{2}}, \quad, \mathrm{i}=1, \ldots, \mathrm{m}
$$

Akhirnya masing-masing lokasi taman kota memiliki nilai kedekatan relatif (relative closeness) yang mencerminkan dekat atau jauhnya sebuah lokasi taman kota dengan solusi ideal positif dan negatif, dengan rumus:

$$
c_{i}^{+}=\frac{d_{i}^{-}}{d_{i}^{-}+d_{i}^{+}}
$$

$$
, \mathrm{i}=1, \ldots, \mathrm{m}
$$

Semakin tinggi nilai $c_{i}^{+}$maka sebuah taman kota semakin dekat dengan solusi ideal positif, dan semakin kecil $c_{i}^{+}$maka taman kota tersebut semakin jauh dengan solusi ideal positif.

\section{HASIL DAN PEMBAHASAN}

Data spasial panjang jalan, luas taman, dan jumlah taman potensial di tiap kecamatan di Kota Depok disajikan dalam Tabel 2. Untuk memperoleh data panjang jalan di setiap lokasi taman kota potensial, digunakan dengan menggunakan metode clip dimana data panjang jalan Kota Depok berfungsi sebagai input feature dan lokasi taman kota potensial berfungsi sebagai clip feature. Terlihat pada Tabel 2 untuk luas taman terbesar dan jumlah taman potensial terbanyak berada di Kecamatan Cipayung, sedangkan jumlah panjang jalan terbesar dalam lokasi taman potensial berada di 
Jurnal Pendidikan Geografi:

Kajian, Teori, dan Praktik dalam Bidang Pendidikan dan Ilmu Geografi

Volume 25, Nomor 2, Jun 2020, Hal 145-160

Kecamatan Tapos. Sedangkan nilai terkecil untuk luas taman, jumlah taman dan panjang jalan dimiliki oleh Kecamatan Cinere.

Untuk membandingkan antar data spasial berbentuk tabular yang digunakan di tiap kecamatan, maka data tabular dinormalisasi dengan membagi masing-masing nilai dengan nilai maksimum atau dikenal dengan metode linear scale transformation (max) (Celen, 2014). Hasil dari normalisasi dengan metode 'max' adalah interval data ternormalisasi diantara 1 dan 0 (Cendrero, 2018), apabila data tidak memiliki nilai negatif. Transformasi data menjadi data ternormalisasi dengan metode 'max' (Dorpe, 2018) dilakukan dengan persamaan :

$$
x^{\prime}=\frac{x}{\max (x)}
$$

dimana $x^{\prime}=$ data ternormalisasi, $\mathrm{x}=$ data.

Dengan menggunakan persamaan (8) maka setiap data hasil normalisasi mempunyai interval antara 1 dan 0 , hal ini mengakibatkan bahwa nilai terbesar di setiap data adalah 1 sehingga data panjang jalan, luas taman dan jumlah taman tiap kecamatan layak untuk dibandingkan karena mempunyai interval yang sama (Tabel 2 dan Gambar $3)$.

Dapat diamati pada Gambar 3, bahwa Kecamatan Cipayung memiliki jumlah taman kota potensial dan luas taman potensial yang terbesar dibandingkan dengan kecamatan lainnya. Namun total panjang jalan ternormalisasi dalam lokasi taman potensial di Kecamatan Cipayung hanya sebesar 0,61, masih di bawah Kecamatan Tapos $(1,00)$ dan Bojongsari $(0,97)$. Bagi pengambil kebijakan, hal ini berimplikasi bahwa pembangunan lokasi taman kota di Kecamatan Cipayung memerlukan akses jalan yang besar dibandingkan pembangunan taman di Kecamatan Tapos dan Bojongsari yang akses jalannya lebih besar. Lokasi taman kota yang kurang memiliki akses akan mengurangi manfaat bagi pengunjung yang dekat dengan lokasi taman kota. Hal ini berdasarkan penelitian sebelumnya (Brown, Rhodes, \& Daded, 2018) bahwa akses jalan yang lebih besar kepada taman kota dapat meningkatkan manfaat bagi pengunjung, yaitu semakin dekat jarak taman kota dengan lokasi domisili rumah tinggal semakin disukai untuk aktivitas pengunjung dengan tingkat aktivitas fisik tinggi dan menengah seperti latihan fisik dengan peralatan, berjalan dengan anjing peliharaan, dan berlari/jogging.

Tabel 2. Data luas taman, jumlah taman potensial, panjang jalan dan normalisasinya di tiap kecamatan

\begin{tabular}{lcccccc}
\hline Kecamatan & $\begin{array}{c}\text { Luas } \\
\text { taman } \\
\text { potensial } \\
\text { (hektar) }\end{array}$ & $\begin{array}{c}\text { Luas taman } \\
\text { potensial } \\
\text { (normalisasi) }\end{array}$ & $\begin{array}{c}\text { Jumlah } \\
\text { taman } \\
\text { potensial }\end{array}$ & $\begin{array}{c}\text { Jumlah taman } \\
\text { potensial } \\
\text { (normalisasi) }\end{array}$ & $\begin{array}{c}\text { Panjang jalan } \\
\text { dalam lokasi } \\
\text { taman } \\
\text { potensial } \\
\text { (m) }\end{array}$ & $\begin{array}{c}\text { Panjang jalan } \\
\text { dalam lokasi } \\
\text { taman } \\
\text { potensial } \\
\text { (normalisasi) }\end{array}$ \\
\hline Cipayung & 93,24 & 1,00 & 19 & 1,00 & 8563,34 & 0,61 \\
Bojongsari & 90,73 & 0,97 & 17 & 0,89 & $13.884,18$ & 0,97 \\
Pancoran Mas & 77,08 & 0,83 & 13 & 0,68 & 8324,24 & 0,60 \\
Limo & 62,94 & 0,68 & 12 & 0,63 & 7960,10 & 0,57 \\
Tapos & 60,76 & 0,65 & 13 & 0,68 & $13.946,84$ & 1,00 \\
Cilodong & 49 & 0,53 & 9 & 0,47 & 4973,27 & 0,36 \\
Cimanggis & 47,71 & 0,51 & 9 & 0,47 & 7371,00 & 0,53 \\
Sawangan & 40,28 & 0,43 & 7 & 0,37 & 5549,28 & 0,40 \\
Beji & 25,66 & 0,28 & 7 & 0,37 & 4308,98 & 0,31 \\
Sukma Jaya & 22,32 & 0,24 & 5 & 0,26 & 3803,68 & 0,27 \\
Cinere & 15,94 & 0,17 & 2 & 0,11 & 2971,83 & 0,21 \\
\hline
\end{tabular}

(Sumber : Pengolahan data) 
Jurnal Pendidikan Geografi:

Kajian, Teori, dan Praktik dalam Bidang Pendidikan dan Ilmu Geografi

Volume 25, Nomor 2, Jun 2020, Hal 145-160

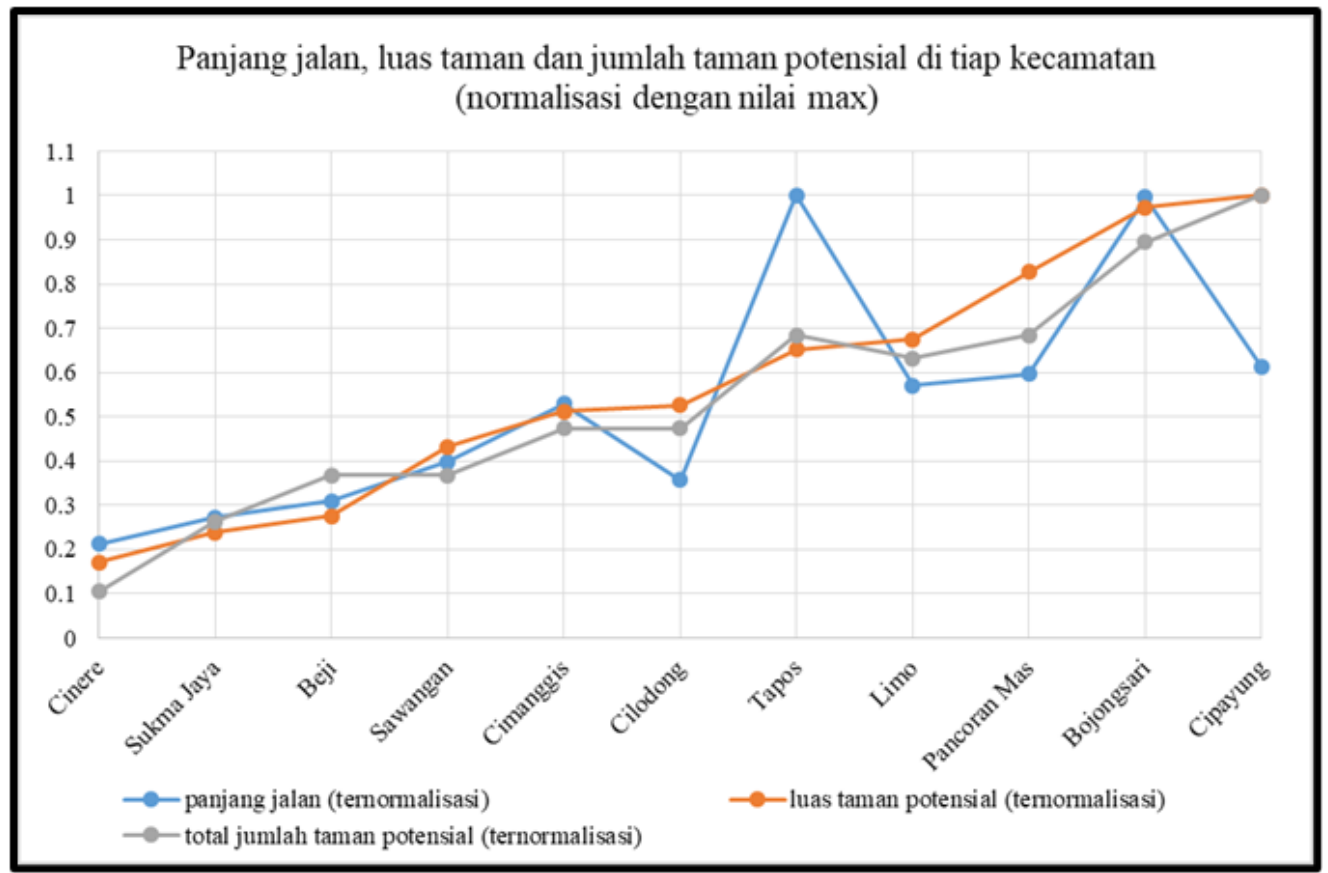

Gambar 3. Grafik data ternormalisasi panjang jalan, luas taman dan jumlah taman di tiap kecamatan (Sumber: Pengolahan data menggunakan ArcGIS)

Tabel 3. Normalisasi nilai attribut setiap kriteria

\begin{tabular}{|c|c|c|c|c|c|c|}
\hline Lokasi & $\begin{array}{l}(k 1) \\
(\mathrm{m})\end{array}$ & $\begin{array}{r}(k 2) \\
(0-1)\end{array}$ & $\begin{array}{l}(k 3) \\
\left(\mathrm{m}^{2}\right)\end{array}$ & Normalisasi $k 1$ & Normalisasi $k 2$ & Normalisasi $\boldsymbol{k 3}$ \\
\hline 1 & 1.250 & 0,67 & 83.011 & 0,007547 & 0,00411 & 0,001989 \\
\hline 2 & 2.844 & 0,67 & 358.890 & 0,009255 & 0,00411 & 0,002601 \\
\hline ......... & $\ldots \ldots \ldots$ & ......... & ......... & ........ & $\ldots \ldots \ldots$ & $\ldots \ldots \ldots$ \\
\hline 113 & 0 & 0,33 & 28.885 & 0 & 0,006134 & 0,000391 \\
\hline Jumlah & 87.659 & 53,8 & 10.181 .509 & 0,5 & 0,33 & 0,17 \\
\hline
\end{tabular}

(Sumber : Pengolahan data)

Dapat diamati bahwa di Kecamatan Cinere, Sukma Jaya, Beji, Sawangan dan Cimanggis perbandingan data panjang jalan, luas taman dan jumlah taman ternormalisasi hampir sama (Gambar 3). Ke-4 kecamatan ini bisa menjadi alternatif pembangunan taman kota selain kecamatan lainnya, apabila biaya pembangunan menjadi pertimbangan bagi pengambil kebijakan, hal ini karena semakin luas dan jumlah taman kota yang banyak memerlukan biaya yang relatif besar.

Hasil normalisasi data setiap lokasi potensial taman kota menggunakan persamaan (2) dengan penerapan menu query, statistics dan field calculator pada ArcGIS dapat dilihat pada Tabel 3.

Setiap lokasi potensial taman kota di tingkat kecamatan yang telah mempunyai bobot dari Tabel 3 dapat ditampilkan dalam bentuk data vektor. Untuk menampilkan data klasifikasi vektor lokasi potensial berdasarkan bobot panjang jalan, maka dilakukan pembagian kelas menggunakan interval yang sama atau menu equal interval pada piranti lunak ArcGIS. Metode equal interval menitikberatkan pada jumlah nilai sebuah atribut dibandingkan secara relatif dengan nilai lainnya (ESRI, 2020). Pada studi ini, lokasi 
Jurnal Pendidikan Geografi:

Kajian, Teori, dan Praktik dalam Bidang Pendidikan dan Ilmu Geografi

Volume 25, Nomor 2, Jun 2020, Hal 145-160

potensial berdasarkan bobot panjang jalan dan luas lokasi dibagi menjadi 5 klas, yaitu sangat besar, besar, sedang, kecil dan sangat kecil (Gambar 4).

Lokasi potensial taman kota yang termasuk dalam kelompok bobot terbesar berdasarkan kriteria luas lokasi, disajikan dalam Gambar 5 dimana klasifikasi lokasi dilakukan dengan menggunakan metode equal interval. Pada Gambar 5, lokasi potensial yang termasuk ke dalam kelompok bobot terbesar disimbolkan dengan lingkaran berwarna hijau, sedangkan lingkaran warna merah termasuk ke dalam kelompok dengan bobot terkecil. Dapat diamati pada Gambar 5 bahwa hanya di Kecamatan Beji yang tidak memiliki lokasi potensial dari kelompok bobot terbesar $(0,0037-0,004)$ dan kedua terbesar (0,0027-0,0036).

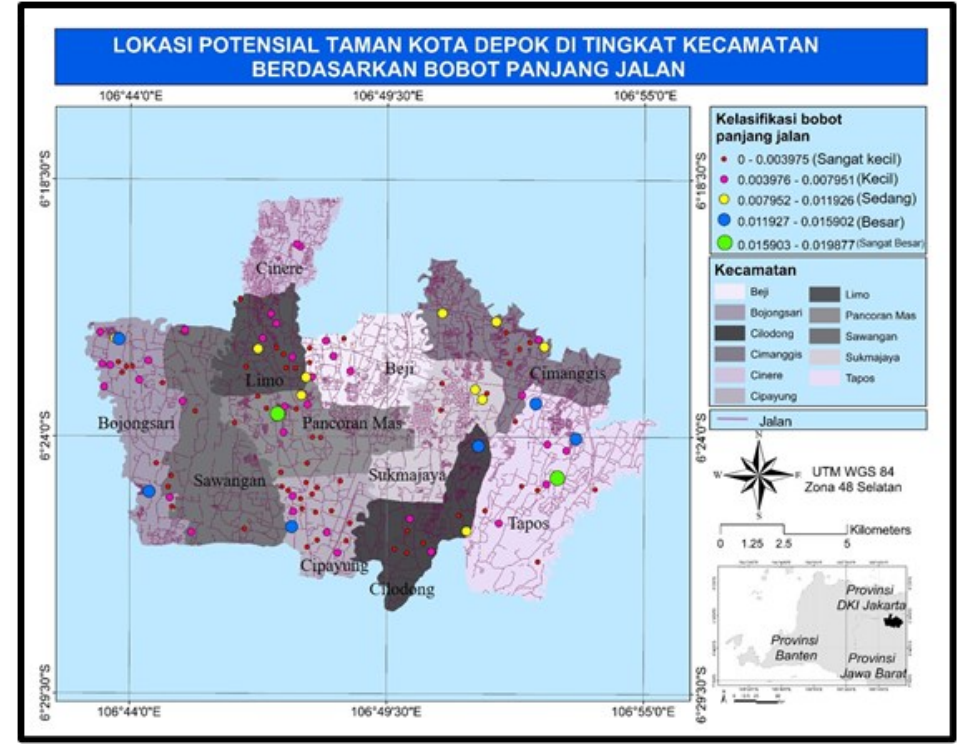

Gambar 4. Lokasi potensial taman kota berdasarkan kelasifikasi bobot panjang jalan (Sumber: Pengolahan data menggunakan ArcGIS)

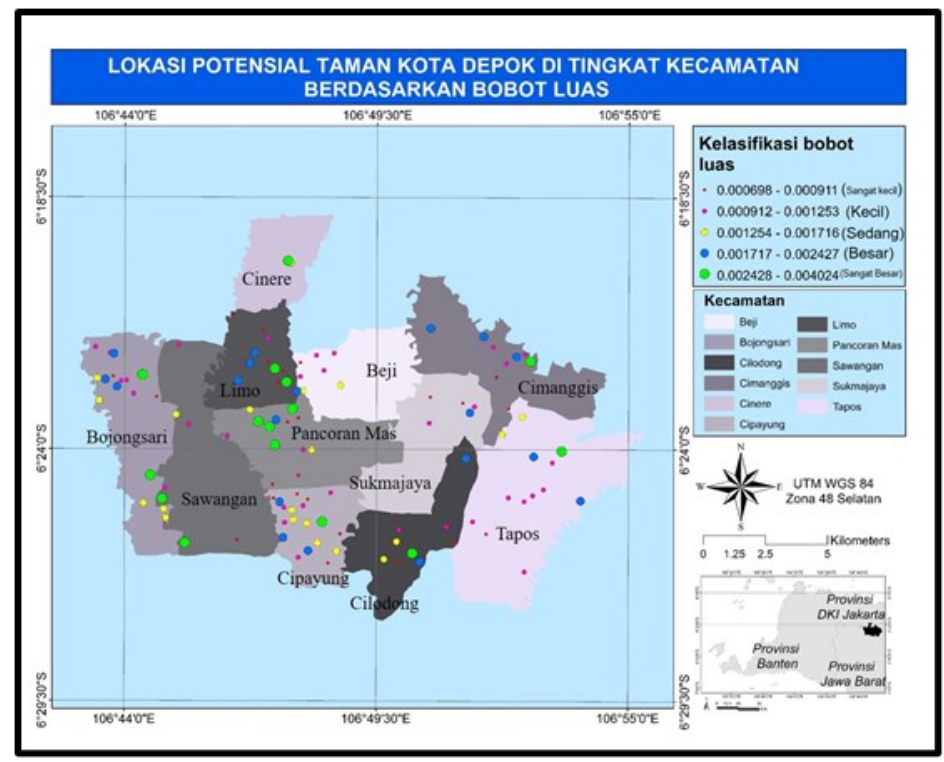

Gambar 5. Lokasi potensial taman kota berdasarkan kelasifikasi bobot luas (Sumber: Pengolahan data menggunakan $\operatorname{ArcGIS}$ ) 
Jurnal Pendidikan Geografi:

Kajian, Teori, dan Praktik dalam Bidang Pendidikan dan Ilmu Geografi

Volume 25, Nomor 2, Jun 2020, Hal 145-160

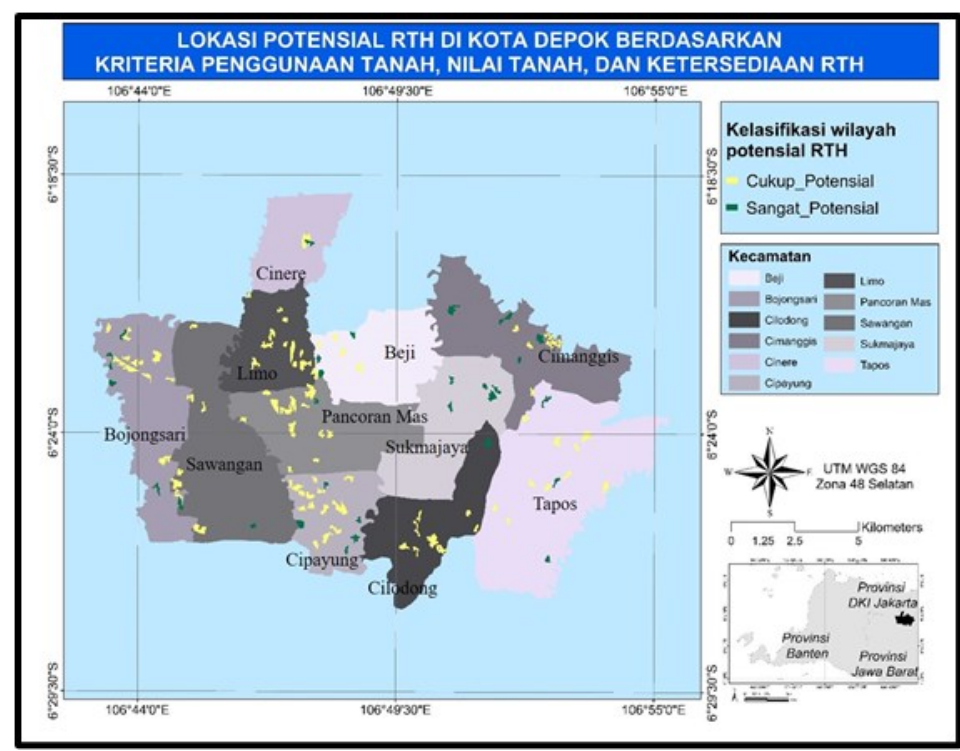

Gambar 6. Lokasi potensial RTH berdasarkan penggunaan tanah, nilai tanah dan ketersediaan RTH (Sumber: Diolah dari Abdurrohim (2017)

Tabel 4. Solusi ideal positif $\left(r^{+}\right)$dan solusi ideal negatif $\left(r^{-}\right)$

\begin{tabular}{lccc}
\hline Solusi ideal & $k 1$ & $k 2$ & $k 3$ \\
\hline$r^{+}$ & 0,019877 & 0,002379 & 0 \\
$r^{-}$ & 0 & 0 & 0,003326 \\
\hline
\end{tabular}

(Sumber : Pengolahan data)

Kriteria spasial ketiga yang digunakan dalam artikel ini adalah klasifikasi lokasi potensial RTH yang terdiri dari 2 kelas yaitu Cukup Potensial (CP) dan Sangat Potensial (SP). Distribusi spasial dari lokasi potensial RTH dapat dilihat pada Gambar 6, dimana lokasi berklasifikasi CP dan SP terdapat diseluruh kecamatan.

Selanjutnya dengan menggunakan persamaan (3) dan (4) dapat diperoleh nilai solusi ideal positif $\left(r^{+}\right)$dan solusi ideal negatif $\left(r^{-}\right)$(Tabel 4).

Dengan menggunakan persamaan (7), maka nilai $d_{i}^{-}$dari persamaan (5) dan $d_{i}^{+}$ dari persamaan (6) diolah menjadi $c_{i}^{+}$yang menunjukkan bahwa peringkat 1 lokasi taman kota dengan nilai $c_{i}{ }^{+}$terbesar $(0,832)$ berada di terletak di Kelurahan Rangkapan Jaya Kecamatan Pancoran Mas dengan luas sekitar 9,06 hektar. Sedangkan lokasi taman kota dengan nilai $c_{i}^{+}$terkecil $(0,039)$ berada di terletak di Kelurahan Rangkapan Jaya Baru Kecamatan Pancoran Mas, dengan luas sekitar 10,4 hektar (Tabel 5). Pada Tabel 5 terlihat bahwa lokasi taman potensial yang tidak memiliki jaringan jalan berada di peringkat bawah yaitu diantaranya peringkat 108-113 sedangkan pada peringkat 1 lokasi potensial memiliki akses jalan yang paling besar. Hasil ini memberikan banyak pilihan bagi pengambil keputusan apabila peringkat yang lebih besar mengalami kendala pembangunan maka dapat dipilih lokasi yang peringkatnya lebih rendah.

Dengan menggunakan menu equal interval pada $\operatorname{ArcGIS}$, nilai $c_{i}^{+}$dikelompokkan menjadi 5 kelas dimana kelompok dengan nilai tertinggi $c_{i}^{+}$(peringkat 1-6) di beri simbol warna hijau dan kelompok dengan nilai $c_{i}^{+}$terendah (peringkat 81-113) diberi warna merah (Gambar 7).

Dapat diamati pada Gambar 7, Kecamatan Beji dan Limo tidak memiliki kandidat lokasi potensial taman kota dengan rentang nilai $c_{i}^{+} 0,516-0,673$ (peringkat 7-13) dan $c_{i}^{+}$ 
Jurnal Pendidikan Geografi:

Kajian, Teori, dan Praktik dalam Bidang Pendidikan dan Ilmu Geografi

Volume 25, Nomor 2, Jun 2020, Hal 145-160

0,674-0,832 (peringkat 1-6), hal ini mungkin disebabkan oleh minimnya akses jalan ke lokasi taman dan tingginya nilai tanah atau sudah cukup tersedianya RTH. Pada penelitian sebelumnya (Setyani, Sitorus, \& Panuju, 2017), luas RTH Kecamatan Beji pada tahun 2011 adalah 300,73 hektar sedangkan kebutuhan RTH berdasarkan 20\% luas wilayah adalah 286 hektar sehingga terjadi surplus RTH sebesar 14,73 hektar.

Tabel 5. Peringkat alternatif lokasi taman kota tingkat kecamatan hasil metode TOPSIS

\begin{tabular}{|c|c|c|c|c|c|c|c|}
\hline Peringkat & $\begin{array}{c}\text { Kecamatan di } \\
\text { mana lokasi } \\
\text { potensial taman } \\
\text { kota berada }\end{array}$ & $\begin{array}{l}\text { Panjang } \\
\text { jalan di } \\
\text { dalam } \\
\text { lokasi }(\mathrm{m})\end{array}$ & $\begin{array}{c}\text { Kelasifikasi } \\
\text { wilayah } \\
\text { potensial RTH }\end{array}$ & $\begin{array}{l}\text { Luas } \\
\text { lokasi } \\
\left(\mathrm{m}^{2}\right)\end{array}$ & $d_{i}^{+}$ & $d_{i}^{-}$ & $c_{i}^{+}$ \\
\hline 1 & Pancoran Mas & 2.287 & $\mathrm{CP}$ & 90.361 & 0,004301 & 0,0213 & 0,832 \\
\hline 2 & Bojongsari & 1.754 & SP & 45.201 & 0,005248 & 0,0203 & 0,795 \\
\hline 3 & Tapos & 1.929 & $\mathrm{CP}$ & 38.513 & 0,005909 & 0,0197 & 0,769 \\
\hline 4 & Cipayung & 1.739 & SP & 71.936 & 0,006154 & 0,0194 & 0,759 \\
\hline 5 & Tapos & 1.577 & SP & 51.570 & 0,006970 & 0,0186 & 0,727 \\
\hline 6 & Cilodong & 1.485 & SP & 66.810 & 0,008207 & 0,0174 & 0,679 \\
\hline ........ & .......... & …..... & …..... & (n....... & ......... & ......... & ......... \\
\hline 108 & Sawangan & 0 & $\mathrm{CP}$ & 41.287 & 0,022755 & 0,0028 & 0,110 \\
\hline 109 & Cipayung & 0 & $\mathrm{CP}$ & 45.458 & 0,022876 & 0,0028 & 0,106 \\
\hline 110 & $\begin{array}{l}\text { Pancoran } \\
\text { Mas }\end{array}$ & 0 & $\mathrm{CP}$ & 46.791 & 0,022915 & 0,0027 & 0,104 \\
\hline 111 & Cipayung & 0 & $\mathrm{CP}$ & 54.748 & 0,023146 & 0,0026 & 0,095 \\
\hline 112 & Limo & 0 & $\mathrm{CP}$ & 89.368 & 0,024149 & 0,0024 & 0,056 \\
\hline 113 & $\begin{array}{l}\text { Pancoran } \\
\text { Mas }\end{array}$ & 0 & $\mathrm{CP}$ & 103.510 & 0,024560 & 0,0014 & 0,039 \\
\hline
\end{tabular}

(Sumber: Pengolahan data menggunakan $\operatorname{ArcGIS}$ )

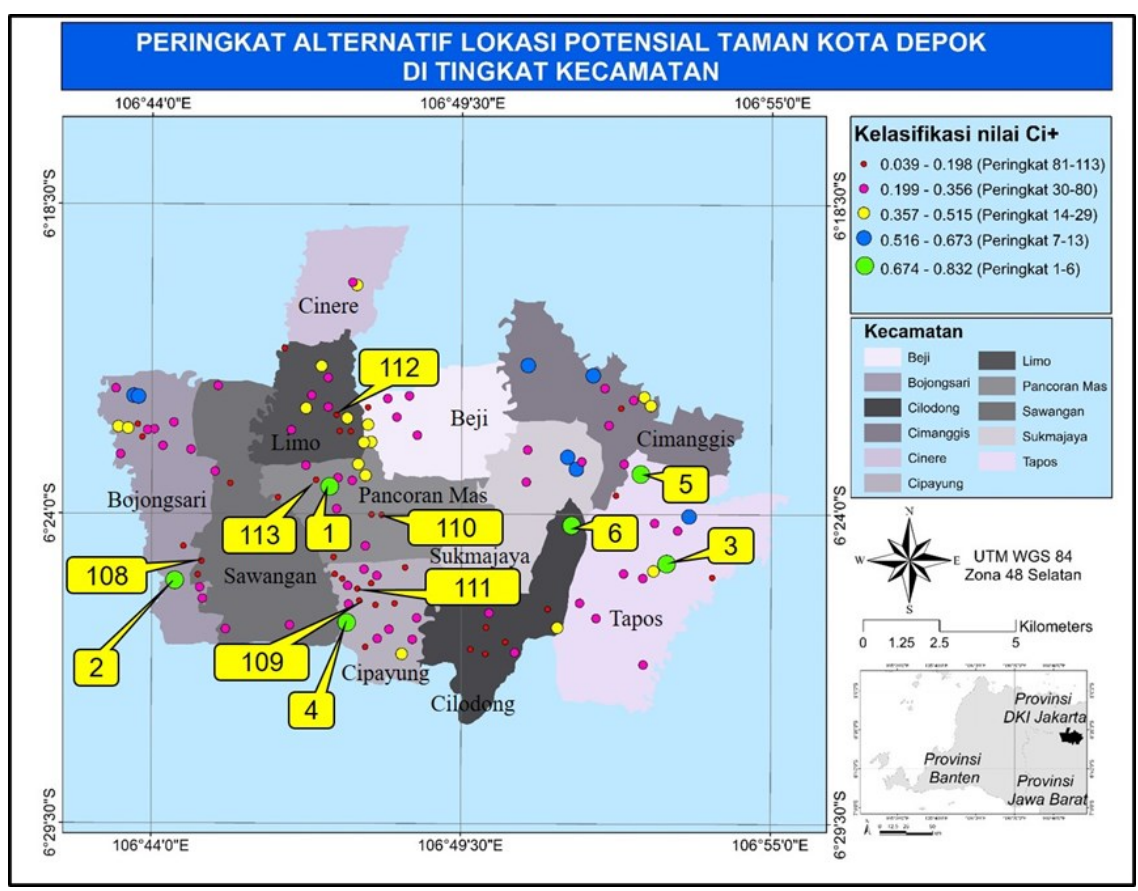

Gambar 7. Peringkat alternatif lokasi potensial taman kota di tingkat kecamatan (Sumber: Pengolahan data menggunakan ArcGIS) 
Jurnal Pendidikan Geografi:

Kajian, Teori, dan Praktik dalam Bidang Pendidikan dan Ilmu Geografi

Volume 25, Nomor 2, Jun 2020, Hal 145-160

Untuk memvalidasi hasil lokasi taman potensial pada studi ini, maka dilakukan analisis foto lokasi (Gambar 8) di rentang peringkat teratas 1-6 dan peringkat terbawah 108-113 dengan memetakan hasil TOPSIS ke dalam aplikasi Google Earth. Tujuan dari analisis foto lokasi taman potensial dari Google Earth adalah memvalidasi bahwa semakin tinggi peringkat taman kota potensial maka akses jalan semakin baik dan semakin rendah peringkat jalan maka akses jalan ke lokasi taman semakin rendah.

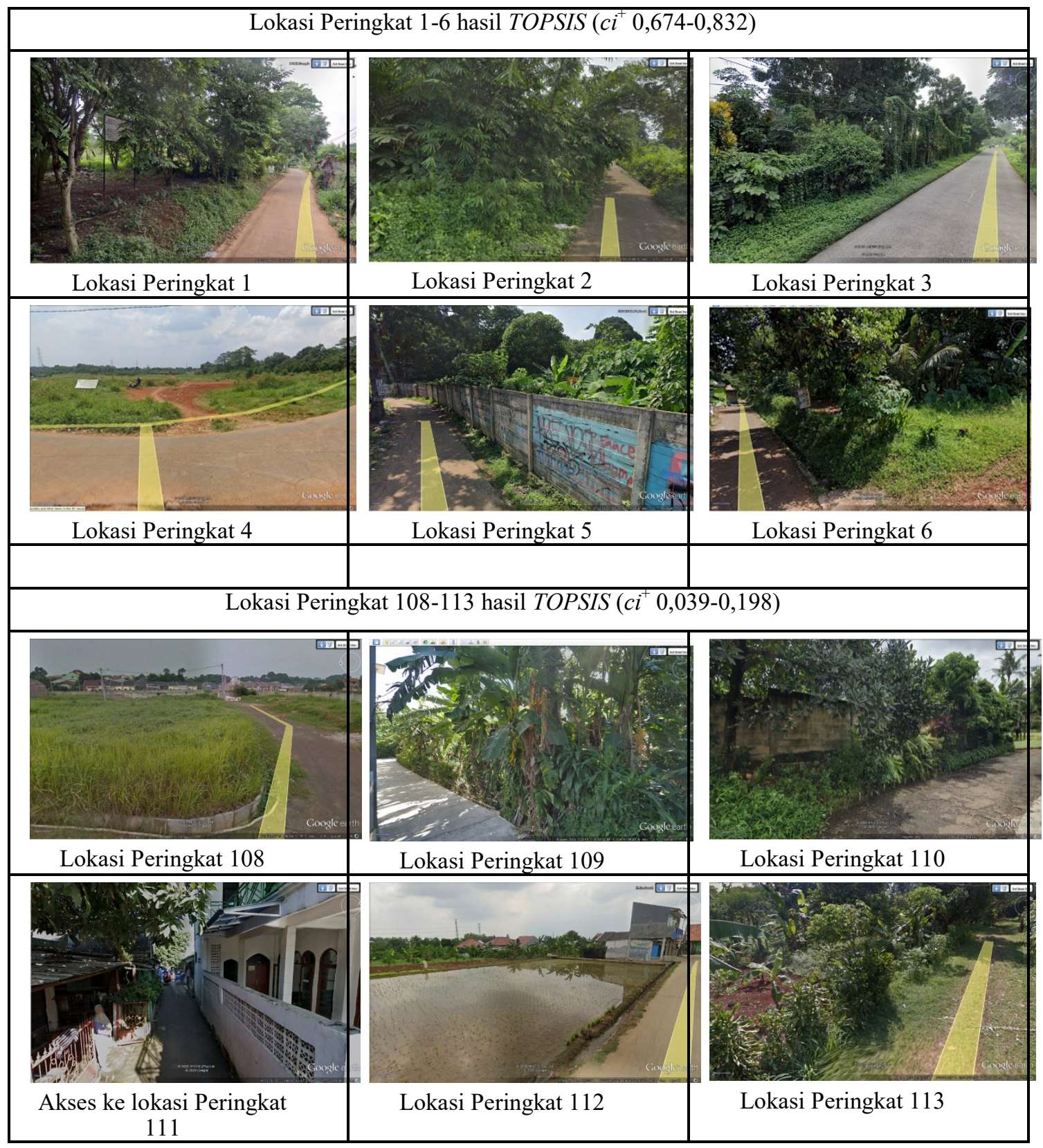

Gambar 8. Foto lokasi Peringkat 1-6 hasil TOPSIS dan Peringkat 108-113 hasil TOPSIS

(Sumber: Google Earth Photo) 
Jurnal Pendidikan Geografi:

Kajian, Teori, dan Praktik dalam Bidang Pendidikan dan Ilmu Geografi

Volume 25, Nomor 2, Jun 2020, Hal 145-160

Dari Gambar 8, dapat diamati bahwa lokasi Peringkat 1-6 memiliki akses jalan yang cukup lebar, sedangkan pada lokasi Peringkat 108-113 akses jalan relatif sempit dan bahkan akses menuju lokasi Peringkat 111 tidak dapat dilalui oleh kendaraan roda 4. Hal ini menunjukkan bahwa hasil analisis TOPSIS telah bekerja secara efektif menseleksi lokasi potensial taman kota berdasarkan kriteria spasial dimana panjang jalan di lokasi mempunyai peringkat 1 atau berbobot 0.5 (Tabel 1). Hal ini tidak terlepas dari prosedur TOPSIS yang mampu mengolah kriteria panjang jalan dan klasifikasi wilayah potensial sebagai benefit indices dan luas taman potensial sebagai cost indices, sehingga dapat diamati dari foto-foto Google Earth bahwa peringkat lokasi terbaik memiliki akses jalan yang baik. Sebagaimana dikemukakan oleh Jozaghi et al. (2018) ketika membandingkan metode TOPSIS dan AHP dalam seleksi pembangunan lokasi dam menggunakan SIG, keunggulan dari metode TOPSIS adalah: (1) lokasi yang dihasilkan memperhitungkan baik solusi ideal negatif $\left(r^{-}\right)$dan positif $\left(r^{+}\right)$dan (2) dapat menggunakan beberapa kriteria yang terdiri dari berbagai unit pengukuran.

\section{Analisis hasil TOPSIS untuk mendukung ketersediaan RTH di Kota Depok}

Mengacu kepada standar RTH di tingkat kecamatan sebagaimana tercantum dalam Peraturan Menteri Pekerjaan Umum Nomor 5 Tahun 2008 tentang Pedoman Penyediaan Dan Pemanfaatan Ruang Terbuka Hijau, maka standar luas taman kecamatan adalah $0,2 \mathrm{~m}^{2}$ per kapita atau 1 taman kecamatan melayani 120.000 jiwa (Direktorat Jenderal Penataan Ruang, 2008). Ketentuan ini apabila dikalkulasikan dengan proyeksi pertumbuhan penduduk Kota Depok sampai dengan tahun 2030 dan 2040 maka akan menghasilkan kebutuhan taman kecamatan dan dapat dianalisis dengan lokasi taman potensial yang dihasilkan metode TOPSIS. Oleh karena itu terlebih dahulu akan dianalisis proyeksi pertumbuhan penduduk Kota Depok tahun 2030 dan 2040 di tiap kecamatan berdasarkan data penduduk Kota Depok tahun 2010 (BPS, 2010) dan 2019 (BPS, 2020) melalui persamaan laju pertumbuhan penduduk metode geometri yang digunakan oleh BPS (Sirusa BPS, 2020):

$$
r=\left(\frac{P_{t}}{P_{0}}\right)^{\frac{1}{t}-1}
$$

dimana $r$ = laju pertumbuhan penduduk, $P_{t}=$ jumlah penduduk tahun $t, P_{o}=$ jumlah penduduk tahun awal, $t=$ periode waktu antara tahun awal dan tahun $t$ (dalam tahun). Proyeksi penduduk tiap kecamatan di Kota Depok tahun 2030 dan 2040 hasil pengolahan persamaan (9) dapat dilihat pada Tabel 6. Selanjutnya dari proyeksi penduduk 2030 dan 2040, dapat dihitung kebutuhan unit taman kecamatan untuk setiap 120.000 jiwa dan kebutuhan luas taman kecamatan dengan standar $0,2 \mathrm{~m}^{2} /$ penduduk (Tabel 6).

Untuk menganalisis antara kecukupan taman kecamatan hasil metode TOPSIS dengan proyeksi penduduk Kota Depok di tiap kecamatan pada tahun 2030 dan 2040, maka digunakan 3 skenario pembangunan taman kecamatan hasil metode TOPSIS. Pengembangan skenario berdasarkan prosentase pembangunan bahwa proses pengadaan lahan untuk RTH seringkali mengalami kendala baik biaya maupun administratif, sehingga keberhasilan dan batasan tiap skenario merupakan informasi penting bagi pengambil kebijakan RTH. Selain itu, skenario pembangunan taman ini penting untuk melihat sejauh mana keberhasilan metode TOPSIS untuk mengantisipasi bertambahnya kebutuhan RTH akibat proyeksi penduduk Kota Depok pada tahun 2030 dan 2040. Ketiga skenario tersebut adalah skenario I, pembangunan 100\% lokasi taman kecamatan 
Jurnal Pendidikan Geografi:

Kajian, Teori, dan Praktik dalam Bidang Pendidikan dan Ilmu Geografi

Volume 25, Nomor 2, Jun 2020, Hal 145-160

hasil metode TOPSIS dengan jumlah 113 lokasi dengan luas total sebesar 585,66 hektar, skenario II, pembangunan 50\% lokasi taman kecamatan hasil metode TOPSIS dengan jumlah 57 lokasi dengan luas total sebesar 292,83 hektar, dan skenario III, pembangunan $10 \%$ lokasi taman kecamatan hasil metode TOPSIS dengan jumlah 11 lokasi dengan luas total sebesar 58,57 hektar.

Tabel 6. Proyeksi penduduk di Kota Depok tahun 2030 dan 2040 serta kebutuhan unit dan luas taman

\begin{tabular}{|c|c|c|c|c|c|c|c|c|c|}
\hline \multirow[t]{2}{*}{ Kecamatan } & \multirow[t]{2}{*}{$\begin{array}{l}\text { Jumlah } \\
\text { pendudu } \\
\text { k } 2010 \\
\text { (BPS, } \\
\text { 2010) }\end{array}$} & \multirow[t]{2}{*}{$\begin{array}{c}\text { Jumlah } \\
\text { penduduk } \\
2019 \\
\text { (BPS, } \\
2020)\end{array}$} & \multirow[t]{2}{*}{$\boldsymbol{r}$} & \multicolumn{2}{|c|}{$\begin{array}{l}\text { Proyeksi penduduk } \\
\text { (jiwa) }\end{array}$} & \multicolumn{2}{|c|}{$\begin{array}{l}\text { Kebutuhan } \\
\text { unit taman } \\
\text { kecamatan per } \\
120.000 \text { jiwa }\end{array}$} & \multicolumn{2}{|c|}{$\begin{array}{c}\text { Kebutuhan luas } \\
\text { taman kecamatan } \\
\text { (hektar) } \\
\text { berdasarkan } \\
\text { jumlah penduduk } \\
\left(0,2 \mathrm{~m}^{2} / \text { penduduk }\right)\end{array}$} \\
\hline & & & & 2030 & 2040 & 2030 & 2040 & 2030 & 2040 \\
\hline Limo & 87.615 & 121.760 & 0,0372 & 182.051 & 262.421 & 2 & 2 & 3,64 & 5,25 \\
\hline Bojong Sari & 99.768 & 138.070 & 0,0368 & 205.383 & 294.681 & 2 & 2 & 4,11 & 5,89 \\
\hline Cinere & 107.830 & 148.766 & 0,0364 & 220.458 & 315.224 & 2 & 3 & 4,41 & 6,30 \\
\hline Sawangan & 123.356 & 171.068 & 0,0370 & 255.114 & 366.878 & 2 & 3 & 5,10 & 7,34 \\
\hline Cilodong & 123.713 & 173.066 & 0,0380 & 260.860 & 378.794 & 2 & 3 & 5,22 & 7,58 \\
\hline Cipayung & 127.707 & 177.085 & 0,0370 & 264.057 & 379.698 & 2 & 3 & 5,28 & 7,59 \\
\hline Pancoran Mas & 210.204 & 291.429 & 0,0370 & 434.466 & 624.617 & 4 & 5 & 8,69 & 12,49 \\
\hline Tapos & 216.581 & 299.322 & 0,0366 & 444.512 & 636.817 & 4 & 5 & 8,89 & 12,74 \\
\hline Beji & 164.682 & 299.671 & 0,0688 & 622.903 & 1.211 .457 & 5 & 10 & 12,46 & 24,23 \\
\hline Sukmajaya & 232.895 & 321.600 & 0,0365 & 477.109 & 682.883 & 4 & 6 & 9,54 & 13,66 \\
\hline Cimanggis & 242.214 & 334.989 & 0,0367 & 497.918 & 713.899 & 4 & 6 & 9,96 & 14,28 \\
\hline
\end{tabular}

(Sumber: Pengolahan data)
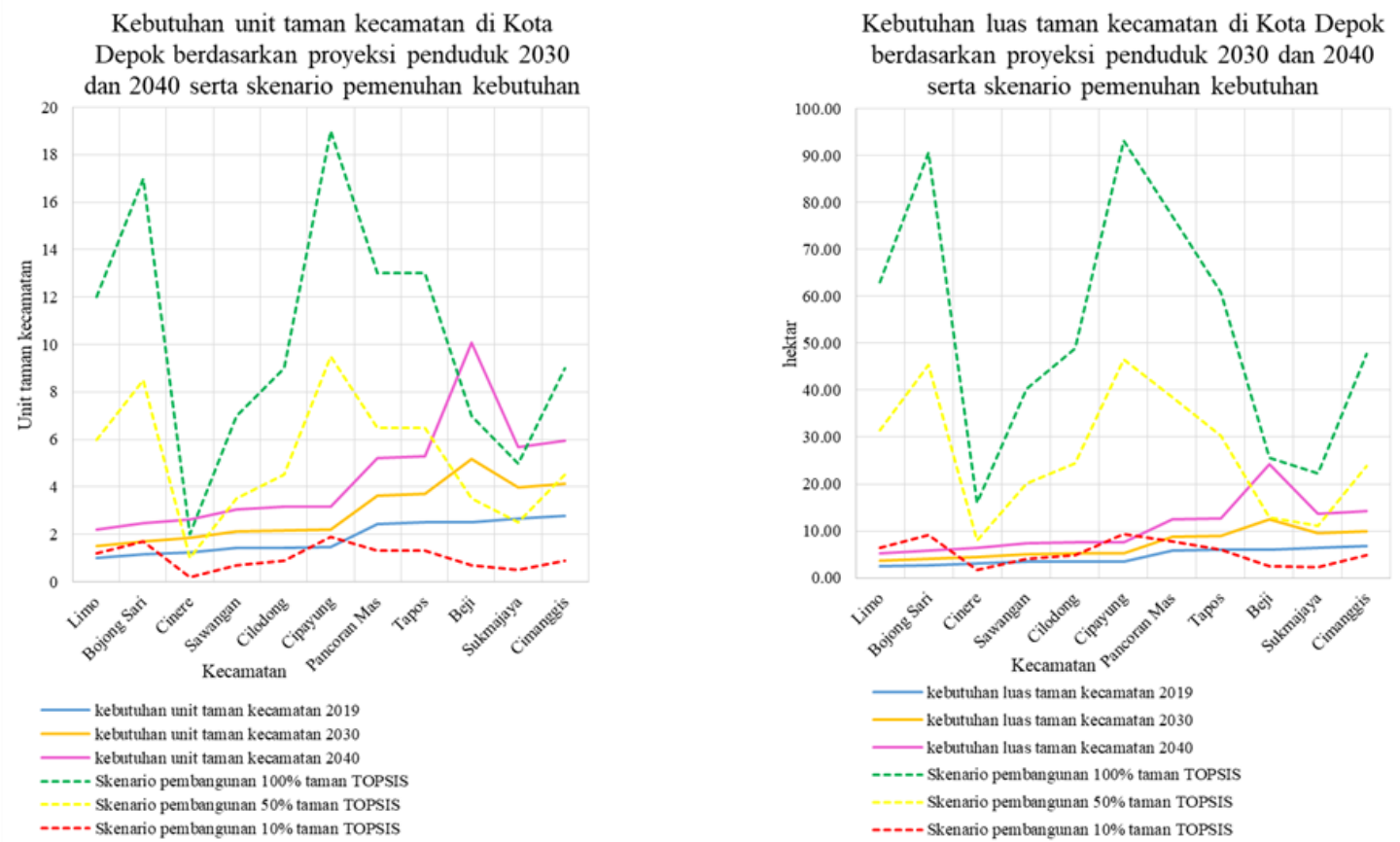

Gambar 9. (a) Kebutuhan unit taman kecamatan di Kota Depok berdasarkan proyeksi penduduk 2030 dan 2040 serta skenario pemenuhan kebutuhan, (b) Kebutuhan luas taman kecamatan di Kota Depok berdasarkan proyeksi penduduk 2030 dan 2040 serta skenario pemenuhan kebutuhan

(Sumber: Pengolahan data) 
Jurnal Pendidikan Geografi:

Kajian, Teori, dan Praktik dalam Bidang Pendidikan dan Ilmu Geografi

Volume 25, Nomor 2, Jun 2020, Hal 145-160

Pada Gambar 9(a) dapat dilihat skenario III (garis putus-putus merah) hanya bisa memenuhi kebutuhan unit taman tahun 2019 di Kecamatan Limo, Bojongsari, dan Cipayung dan tidak mampu memenuhi kebutuhan unit taman di semua kecamatan tahun 2030 dan 2040. Untuk skenario II (garis putus-putus kuning) mampu memenuhi kebutuhan unit taman pada tahun 2040 di 7 kecamatan (Limo, Bojongsari, Sawangan, Cilodong, Cipayung, Pancoran Mas, Tapos). Sedangkan skenario I (garis putus-putus hijau) masih bisa melayani kebutuhan unit taman tahun 2040 di 8 kecamatan atau $72,72 \%$ dari total kecamatan di Kota Depok.

Pada Gambar 9(b), penerapan skenario I (garis putus-putus hijau) mampu memenuhi kebutuhan luas taman di seluruh kecamatan tahun 2019, 2030, dan 2040. Sedangkan skenario II (garis putus-putus kuning) bisa memenuhi kebutuhan luas taman tahun 2019 dan 2030, tetapi pada tahun 2040 hanya mampu memenuhi 9 kecamatan atau $81,82 \%$ dari total kecamatan. Skenario III (garis putus-putus merah) sudah mampu memenuhi kebutuhan luas taman tahun 2019, 2030, dan 2040 di 3 kecamatan (Limo, Bojongsari, Cipayung) atau 27,27\% dari total kecamatan di Kota Depok.

Melihat minimnya capaian skenario III untuk pemenuhan luas taman dan kebutuhan unit taman (Gambar 9), maka penerapan skenario I atau II perlu dilakukan dan apabila terkendala oleh pendanaan maka pengambil kebijakan memerlukan alternatif pembiayaan untuk pengadaan lahan. Alternatif pembiayaan pembangunan taman kota selain dari Anggaran Pembangunan dan Belanja Daerah (APBD), bisa melalui program Corporate Social Responsibility (CSR) perusahaan sebagai konstribusi terhadap pembangunan daerah (Wardana, 2018).

\section{KESIMPULAN}

Kombinasi SIG dan TOPSIS telah berhasil membuat peringkat alternatif 113 lokasi potensial taman Kota Depok di tingkat kecamatan dengan mengolah 3 kriteria yang berbeda unit pengukuran secara bersandingan (commensurable) yaitu; akses jalan, wilayah potensial RTH, dan luas lokasi. Hasil validasi mengindikasikan bahwa pemberian bobot tertinggi pada kriteria panjang jalan sebagai solusi ideal positif pada metode TOPSIS, akan menjamin akses jalan yang semakin baik pada semakin tingginya peringkat lokasi potensial taman kecamatan. Dapat disimpulkan bahwa pembangunan 100\% lokasi taman hasil TOPSIS (skenario I) diprediksikan masih mampu melayani kebutuhan luas taman kecamatan di Kota Depok sampai dengan tahun 2040. Sedangkan untuk memenuhi kebutuhan unit taman kecamatan sampai dengan tahun 2040, skenario I masih bisa diaplikasikan pada 8 kecamatan atau $72,72 \%$ dari total kecamatan di Kota Depok.

\section{DAFTAR RUJUKAN}

Abdurrohim, Y. (2017). Wilayah potensial pemenuhan target ruang terbuka hijau di Kota Depok. Universitas Indonesia.

Brown, G., Rhodes, J., \& Dade, M. (2018). An evaluation of participatory mapping methods to assess urban park benefits. Landscape and Urban Planning, 178, 18-31.

Çelen, A. (2014). Comparative analysis of normalization procedures in TOPSIS method: with an application to Turkish deposit banking market. Informatica, 25(2), 185-208.

Cendrero, S. M. (2018, November 1). Warning About Normalizing Data. Artificial Intelligence. Retrieved from https://business.blogthinkbig.com.

Depok, P. K. (2015). Peraturan Daerah Kota Depok No. 1 Tahun 2015 Tentang Rencana Tata Ruang Wilayah Kota Depok Tahun 20122032. Indonesia: Pemerintah Kota Depok.

Dorpe, S. V. (2018, December 14). Preprocessing with sklearn: a complete and 
Kajian, Teori, dan Praktik dalam Bidang Pendidikan dan Ilmu Geografi

Volume 25, Nomor 2, Jun 2020, Hal 145-160

comprehensive guide. Normalization 'max'. Retrieved from https:// towardsdatascience.com.

ESRI. (2020). Data classification methods. Retrieved from https://desktop.arcgis.com.

Gupta, K., Roy, A., Luthra, K., \& Maithani, S. (2016). GIS based analysis for assessing the accessibility at hierarchical levels of urban green spaces. Urban forestry \& urban greening, 18, 198-211.

Jozaghi, A., Alizadeh, B., Hatami, M., Flood, I., Khorrami, M., Khodaei, N., \& Ghasemi Tousi, E. (2018). A comparative study of the ahp and topsis techniques for dam site selection using gis: A case study of sistan and baluchestan province, iran. Geosciences, 8(12), 494.

Mafra, R., Siswanto, A., Iqbal, M. M., \& Juliantina, I. (2018). Skala pelayanan tamantaman di Kota Palembang. Jurnal Desiminasi Teknologi, 6(2).

Malczewski, J., \& Rinner, C. (2015). Multicriteria decision analysis in geographic information science (pp. 220-228). New York: Springer.

Meng, Y., \& Malczewski, J. (2015). A GIS-based multicriteria decision making approach for evaluating accessibility to public parks in Calgary, Alberta. Human Geographies, 9(1), 29.

Molaei Qelichi, M., Oroji, H., \& Asadi, S. Optimum locating of urban parks and green space using GIS and TOPSIS technique (Case study: region six of TEHRAN in IRAN).

Setyani, W., Sitorus, S. R. P., \& Panuju, D. R. (2017). Analisis ruang terbuka hijau dan kecukupannya di Kota Depok. Buletin Tanah dan Lahan, 1(1), 121-127.

Sitorus, S. R. P., Ashri, M., \& Panuju, D. R. (2016). Analisis ketersediaan ruang terbuka hijau dan tingkat perkembangan wilayah di Kota Cimahi, Provinsi Jawa Barat. Jurnal Ilmu Tanah dan Lingkungan, 15(2), 66-75.

Statistik, B. P. (2010). Kota Depok dalam angka. Depok: Depok (ID) Badan Pusat Statistik.

Statistik, B. P. (2016). Sistem informasi rujukan statistik. Statistics Indonesia's SIRuSa Statistical Information System] [online]< https://sirusa. bps. go. id/index. php.

Statistik, B. P. (2020). Kota Depok dalam angka. Depok: Depok (ID) Badan Pusat Statistik.

Tang, J., Zhu, H. L., Liu, Z., Jia, F., \& Zheng, X. X. (2019). Urban sustainability evaluation under the modified TOPSIS based on grey relational analysis. International journal of environmental research and public health, 16(2), 256.

Tontou, J. M., Moniaga, I., \& Rengkung, M. (2015). Analisis kebutuhan ruang terbuka hijau di Kota Poso (studi kasus: Kecamatan Poso Kota). Spasial, 2(3), 63-71.

Umum, M. P. (2008). Peraturan menteri pekerjaan umum no. 5 tahun 2008 tentang pedoman penyediaan dan pemanfaatan ruang terbuka hijau di kawasan perkotaan. Jakarta: Departemen Pekerjaan Umum.

Wardana, R. K. (2018). Optimalisasi pemanfaatan aset tanah pemerintah Kota Malang melalui penggunaan dana corporate social responsibilty (cSR). J-3P (Jurnal Pembangunan Pemberdayaan Pemerintahan), 97-111

Wei, J. (2010). TOPSIS method for multiple attribute decision making with incomplete weight information in linguistic setting. Journal of Convergence Information Technology, 5(10), 181-187.

Drope, S. (2018). Preprocessing with sklearn: a complete and comprehensive guide. https://towardsdatascience.com/preprocessing-with-sklearn-a-complete-andcomprehensive-guide-670cb98fcfb9. 